\title{
Spatiotemporal aspects of silica buffering in restored tidal marshes
}

\author{
Sander Jacobs ${ }^{\mathrm{a}, *}$, Eric Struyf ${ }^{\mathrm{a}, \mathrm{b}}$, Tom Maris $^{\mathrm{a}}$, Patrick Meire ${ }^{\mathrm{a}}$ \\ ${ }^{a}$ Department of Biology, Ecosystem Management Research Group, University of Antwerp, Universiteitsplein 1, 2610 Wilrijk, Antwerp, Belgium \\ ${ }^{\mathrm{b}}$ GeoBiosphere Science Centre, Department of Geology, Lund University, Sölvegatan 12, 22362 Lund, Sweden
}

\section{A R T I C L E I N F O}

\section{Article history:}

Received 23 January 2008

Accepted 8 July 2008

Available online 15 July 2008

\section{Keywords:}

wetlands

restoration

tidal flats

nutrient cycles

eutrophication

silica

Schelde estuary

Belgium

$51^{\circ} 03^{\prime} 53^{\prime \prime} \mathrm{N}$

$4^{\circ} 08^{\prime} 55^{\prime \prime} \mathrm{E}$

\begin{abstract}
A B S T R A C T
Losses of pelagic diatom production resulting from silica limitation have not only been blamed for toxic algal blooms, but for the reduction in ability of coastal food webs to support higher trophic levels. Recent research has shown the importance of advective seepage water fluxes of dissolved silica (DSi) from freshwater marshes to pelagic waters during moments of riverine Si-limitation. In this study, we investigated the potential impact of recently installed new tidal areas along the Schelde estuary, located in former polder areas and characterized by so-called controlled reduced tidal regimes (CRT). Nine mass-balance studies were conducted in a newly constructed CRT in the freshwater Schelde estuary. During complete tidal cycles both DSi and amorphous silica (ASi) concentrations were monitored at the entrance culverts and in different habitats in the marsh. A swift DSi-delivery capacity was observed despite the shifted spatiotemporal frame of exchange processes compared to reference marshes. As silica-accumulating vegetation is not yet present, and difference with reference marshes' deliveries is surprisingly small, we indicate diatomaceous debris and phytoliths to be the main silica source. Although further research is necessary on the driving forces of the different processes involved, restoration of former agricultural areas under CRT-regime provide the potential to buffer silica in the estuary.
\end{abstract}

(c) 2008 Elsevier Ltd. All rights reserved.

\section{Introduction}

Estuaries are biogeochemical hot-spots and are amongst the most productive ecosystems of the world (Costanza et al., 1993). As the interface between terrestrial and coastal waters, they support processes that are central to the planet's functioning (Costanza et al., 1997). Estuaries are characterized by steep chemical gradients and complex dynamics, resulting in major transformations in the amount, the chemical nature and the timing of material fluxes.

Eutrophication is one of the most important problems that confronts these systems. Eutrophication phenomena in estuaries are related to the balance between $\mathrm{N}, \mathrm{P}$ and $\mathrm{Si}$ in river loading, and are thus dependent on the interactions between human activity and natural processes in the watershed, which ultimately determine the riverine nutrient delivery into the marine environment (Officer and Ryther, 1980; Billen and Garnier, 1997; Lancelot et al., 1997; Cugier et al., 2005). Eutrophication can cause anoxia, extreme turbidity and even toxicity in coastal areas and lakes, mostly provoked by shifts in plankton community following excessive inputs of $\mathrm{N}$ and $\mathrm{P}$ compared to Si. Decreases in the availability of

\footnotetext{
* Corresponding author.

E-mail addresses: sander.jacobs@ua.ac.be (S. Jacobs), eric.struyf@geol.lu.se (E. Struyf).
}

silica relative to $\mathrm{N}$ and $\mathrm{P}$ in estuaries may result in a shift in the phytoplanktonic community from a dominance of diatoms to other phytoplankton forms as cyanobacteria or toxic dinoflagellate, affecting zooplankton and fisheries (see also Chícharo et al., 2006; Wolanski et al., 2006). Losses of diatom production, resulting from silica limitation, have not only been blamed for these toxic algal blooms, but for the reduction in ability of coastal food webs to support higher trophic levels (Treguer et al., 1995; Cugier et al., 2005; Kimmerer, 2005). Estuarine and marine foodwebs are based essentially on diatoms (Irigoien et al., 2002; Kimmerer, 2005). Dissolved silica concentrations have since long been known to control diatom populations (Wang and Evans, 1969), diatom blooms (Tessenow, 1966; Schelske and Stoermer, 1971; Davis et al., 1978), and seasonal succession in plankton communities (Kilham, 1971). In fact, the availability of dissolved silica (DSi) has been shown to control diatom silica production rates, at least seasonally, in every natural system examined to date (Nelson and Brzezinski, 1990; Nelson and Treguer, 1992; Brzezinski and Nelson, 1996; Nelson and Dortch, 1996; Brzezinski et al., 1998; Bidle and Azam, 2001).

Within the estuarine ecosystem, fringing tidal marshes act as a biogeochemical filter, removing inorganic and organic substances from the floodwaters and changing substance speciation (e.g. Gribsholt et al., 2005). The interaction between tidal marshes and estuaries or coastal zones received much attention through 
numerous exchange studies (e.g. Valiela et al., 2007; Spurrier and Kjerfve, 1988; Whiting et al., 1989; Childers et al., 1993), with emphasis on C, P and N. Dominant questions were whether marshes were importing or exporting N, P, C or particulate matter, often testing the "outwelling" hypothesis (e.g. Dame et al., 1986), which states that a large part of the organic matter produced in the intertidal marshes is not used in internal trophic chains but is transported into the adjacent sea areas and increases their productivity. Only a limited number of mass balance studies have targeted freshwater tidal marshes (e.g. Childers and Day, 1988; Gribsholt et al., 2005; Struyf et al., 2006). The freshwater systems are characterized by botanical properties resembling inland freshwater wetlands and by more direct contact with human-impacted river water. These characteristics make freshwater tidal marshes potentially important process interfaces. Struyf et al. (2006) have shown the importance of advective seepage water fluxes of dissolved silica (DSi) from freshwater marshes to pelagic waters during moments of riverine Si-limitation. Tidal freshwater marshes contain large amorphous silica stocks in marsh soils, built up through sedimentation of diatom shells and incorporation of silica in marsh vegetation (Struyf et al., 2005). Export is the result of consequent dissolution of this amorphous silica (ASi) in marsh pore water from litter and sediments, and advective export of marsh pore- and puddle water between tidal flooding events (Struyf et al., 2007a,b). Silica limitation of diatoms (Conley et al., 1993; Smayda 1997) and the consequent negative effects on food web structure may be avoided. However, data are available only from few tidal freshwater wetlands and conclusions are presently only applicable on a local scale. Furthermore, a recent review stresses the need for more research on silica cycling in wetlands, as it rivals their impact on other biogeochemical cycles and, to date, this topic has not received sufficient attention (Struyf and Conley, in press).

In this study, we investigated the potential impact of recently installed new tidal areas along the Schelde estuary, located in former polder areas and characterized by so-called controlled reduced tidal regimes (CRTs) (Cox et al., 2006; Maris et al., 2007). Along the Schelde estuary, more than $50 \%$ of marsh area will eventually be located in such areas, and may result in international application. This article focuses on the silica biogeochemistry within these new systems and aims to explore spatiotemporal patterns of deposition and dissolution in recently flooded formerly agricultural polder areas. In the first implemented CRT, an intensive spatiotemporal sampling scheme was carried out during the first 16 months of development. This research expands the growing awareness that ecosystems and associated biogenically fixed amorphous $\mathrm{Si}$ rather than geological weathering control silica availability in the aquatic environment on a shorter, biological timescale (Conley, 2002; Humborg et al., 2004; Derry et al., 2005).

\section{Materials and methods}

Nine mass-balance studies were conducted in a newly constructed CRT in the freshwater Schelde estuary: on May 16, July 3, September 10 and 11 and October 10, 2006, and on March 20 and 21 and June 4 and 5, 2007. During nine complete tidal cycles both DSi and ASi concentrations were monitored at the entrance culverts as well as in different habitats in the marsh.

\subsection{Study area}

The Schelde estuary is one of the last European estuaries with a complete fresh- to saltwater tidal gradient, located in the Netherlands and Belgium. Maps and extensive descriptions of hydrology and ecology can be found in several recent papers (Temmerman et al., 2003; Meire et al., 2005; Van Damme et al., 2005; Soetaert et al., 2004). The studied CRT area is a newly constructed inundation area, the "Lippenbroek" (surface approximately $80,000 \mathrm{~m}^{2}$ ), situated at Moerzeke $\left(51^{\circ} 03^{\prime} 53^{\prime \prime} \mathrm{N} ; 4^{\circ} 08^{\prime} 55^{\prime \prime}\right.$ E). Maximal tidal amplitude in the Schelde at this point is approximately $6 \mathrm{~m}$. The area was mostly used as cropland (rotation system with Zea mays and Solanum tuberosum; the lower parts were planted with Populus sp. trees or over-grown with Salix sp. trees (Fig. 1A). The rotation system was abandoned in 2003.

During the two-year construction phase (2003-2005), crops were replaced by pioneer vegetation (mainly Epilobium hirsutum and Urtica dioica) (Fig. 1B). Part of the polder was devegetated due to building construction work (Fig. 1B). Tidal inundation was initiated in March 2006. Since the first inundation, vegetation has been progressively replaced by flood-tolerant species (mainly Lythrum salicaria, Lycopus europaeus and Phragmites australis) (Fig. 2). Because site elevation is several metres under mean high water level, reconstruction of spring-neap tide flooding variation required the construction of separate inlet culvert and outlet culvert (Maris et al., 2007). At the riverside, an inlet culvert permits flooding from $4.80 \mathrm{~m}$ TAW and higher, whilst a valved outlet culvert guarantees one-way emptying from $1.5 \mathrm{~m}$ TAW and lower (TAW is the Belgian Ordnance Level, which is approx. $2.3 \mathrm{~m}$ below mean sea level at the Belgian coast). Consequently, only the top of the tidal cycle is permitted to flood the polder surface. This results in a controlled reduced tidal area (CRT) with unique tidal features, such as a pronounced spring-neap variation and a prolonged stagnant phase (Fig. 3, for details see Cox et al., 2006; Maris et al., 2007). The marsh is surrounded by a dike at $8 \mathrm{~m}$ TAW. Because of the deep artificial dike bases and thick riverine clay deposit in the CRT, ground water fluxes were assumed to be small compared to observed tidal surface water fluxes.
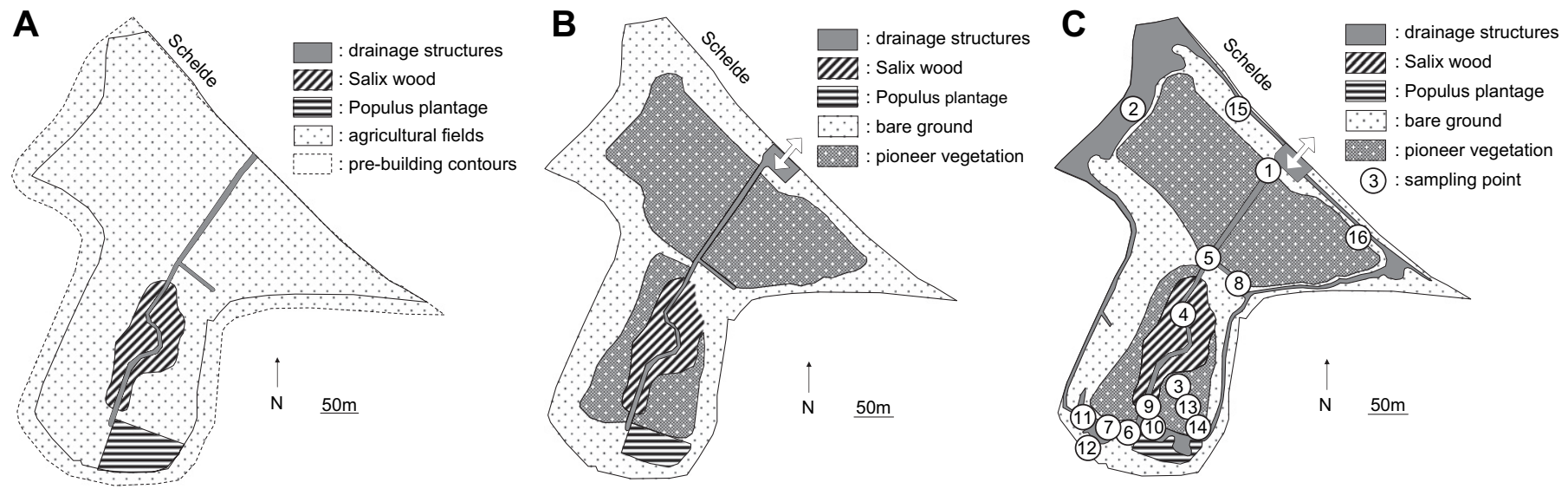

Fig. 1. Schematic overview of study site before (A) and after building works (B). (C) Sampling locations in the CRT. Sampling intensity at locations is given in Tables 1 and 2. 

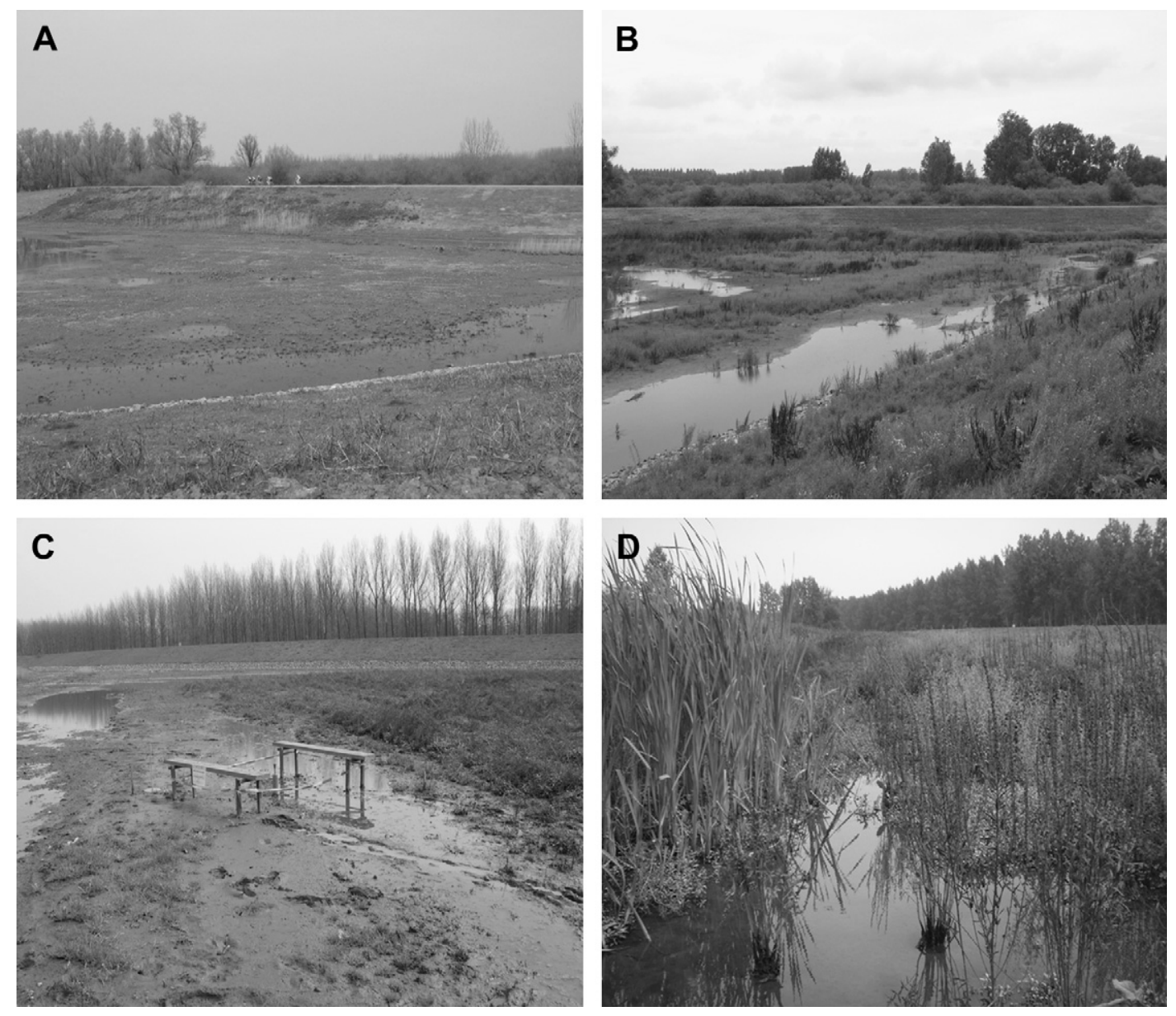

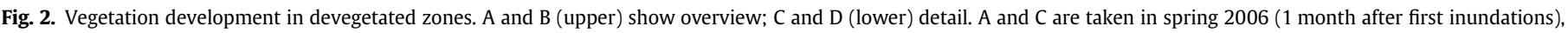
B in summer 2006, and D in summer 2007.

\subsection{Sampling}

A total of 796 data points were obtained during the nine mass balance studies. Surface water samples were collected at the entrance and outlet culvert (1 in Fig. 1C) and in selected habitats throughout the marsh (2-16 in Fig. 1C). Sampling covered the full $13 \mathrm{~h}$ of the tidal cycle for May, July and October 2006 campaigns, and double cycles of one night ("a" in text) plus day ("b" in text) of $26 \mathrm{~h}$ for September 2006 and March and June 2007 campaigns.
Sampling intensity was highest during the first campaign (Tables 1 and 2). This intensity was necessary to explore the spatial patterns in the marsh; however this exhaustive scheme was not entirely repeated during all campaigns. The selection of habitats during subsequent campaigns was based on maximal cover of different habitat features. A selection of samples was analysed for ASi (Table 2), also covering different habitat features.

Samples were taken approximately $10 \mathrm{~cm}$ below the surface, and stored in dark incubators at $5{ }^{\circ} \mathrm{C}$ for a maximum of $24 \mathrm{~h}$.

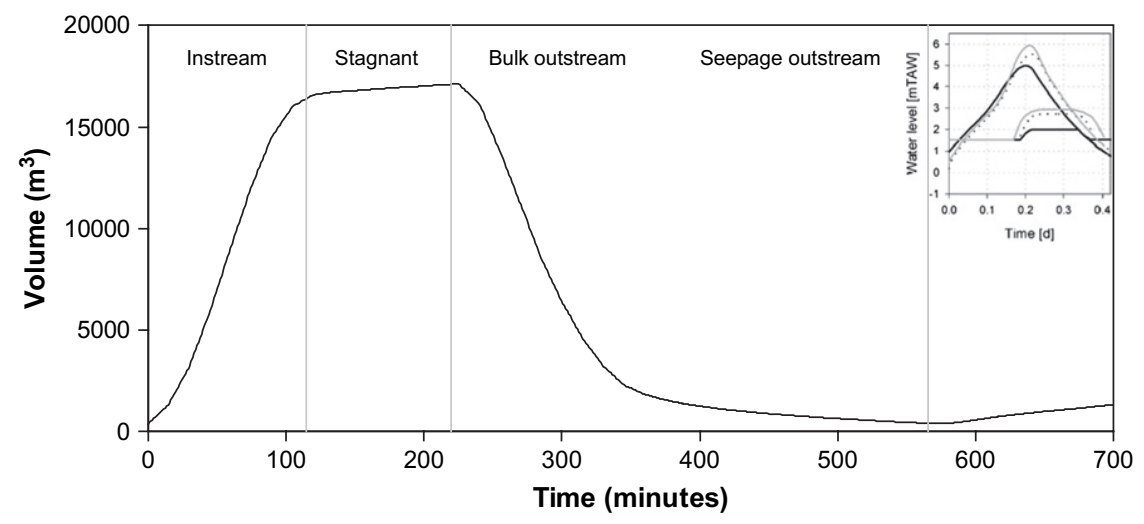

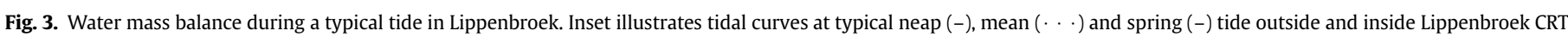

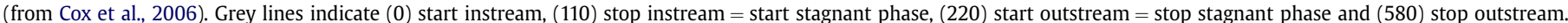

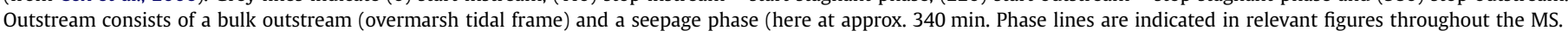



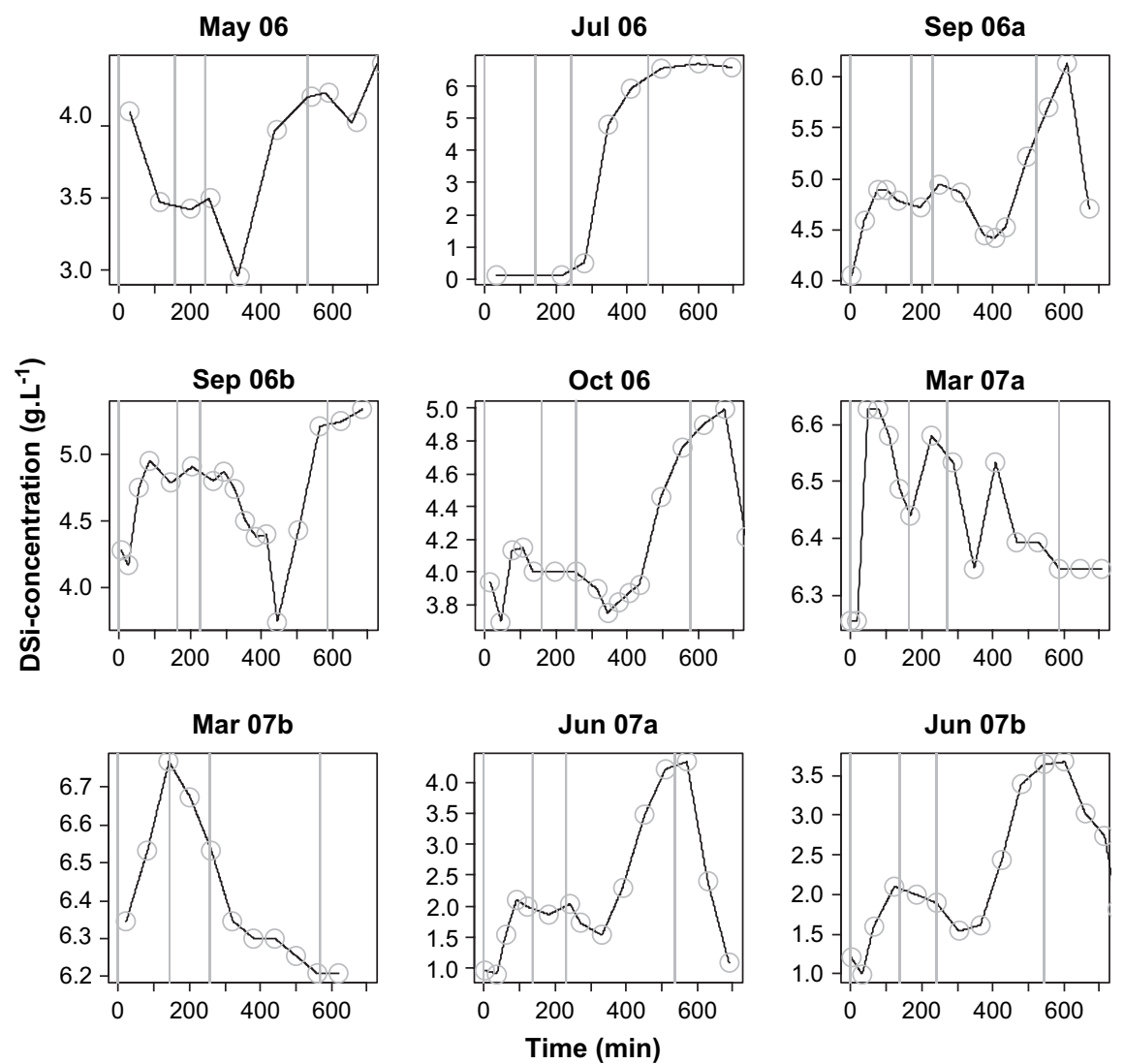

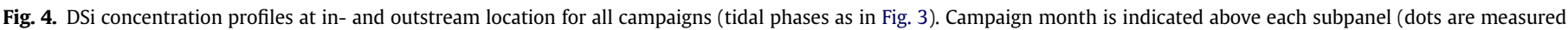
concentrations, lines represent linear extrapolation).

Dissolved silica (DSi) was analysed on a Thermo IRIS ICP (Inductively Coupled Plasmaspectrophotometer) $\left(\right.$ Iris $\left.^{\circledR}\right)$. For each of the samples analysed for ASi (Table 2), three sub samples of $25 \mathrm{ml}$ each were filtered over $0.45-\mu \mathrm{m}$ filters, from a well-mixed total sample of $150 \mathrm{ml}$. After drying at $20^{\circ} \mathrm{C}$, ASi was extracted from the filters in a $0.1 \mathrm{M} \mathrm{Na}_{2} \mathrm{CO}_{3}$ solution at $80^{\circ} \mathrm{C}$ in a shaker bath. Sub samples were taken at 60,120 and $180 \mathrm{~min}$. Blank extractions revealed insignificant DSi release from filters, recipients or chemicals. [ASi] $\left(\mathrm{mg} \mathrm{l}^{-1}\right)$ was then calculated by extrapolating the linear line through the three extraction points in a time-extracted silica plot (DeMaster, 1991). This approach corrects for the additional release of Si from

Table 1

Sampling intensity of DSi samples at different locations (see Fig. 1C) and during different campaigns

\begin{tabular}{|c|c|c|c|c|c|c|c|c|c|c|}
\hline Location & $\begin{array}{l}\text { May } \\
06\end{array}$ & $\begin{array}{l}\text { Jul } \\
06\end{array}$ & $\begin{array}{l}\text { Sep } \\
06 a\end{array}$ & $\begin{array}{l}\text { Sep } \\
\text { 06b }\end{array}$ & $\begin{array}{l}\text { Oct } \\
06\end{array}$ & $\begin{array}{l}\text { Mar } \\
07 a\end{array}$ & $\begin{array}{l}\text { Mar } \\
\text { 07b }\end{array}$ & $\begin{array}{l}\text { Jun } \\
07 a\end{array}$ & $\begin{array}{l}\text { Jun } \\
\text { 07b }\end{array}$ & Total \\
\hline 1 & 53 & 8 & 15 & 17 & 24 & 16 & 11 & 15 & 15 & 174 \\
\hline 2 & 16 & 23 & 57 & 11 & 12 & & & 5 & 5 & 129 \\
\hline 8 & 7 & & 12 & 12 & 12 & & & & & 43 \\
\hline 6 & 10 & 10 & & & 12 & & & 5 & 5 & 42 \\
\hline 5 & 10 & 8 & & & 12 & & & & & 30 \\
\hline 3 & 8 & 8 & & & 12 & & & & & 28 \\
\hline 17 & & 21 & & & & & & & & 21 \\
\hline 4 & 10 & 9 & & & & & & & & 19 \\
\hline 15 & 16 & & & & & & & & & 16 \\
\hline 16 & 14 & & & & & & & & & 14 \\
\hline 12 & 12 & & & & & & & & & 12 \\
\hline 9 & 8 & & & & & & & & & 8 \\
\hline 11 & 7 & & & & & & & & & 7 \\
\hline 10 & 5 & & & & & & & & & 5 \\
\hline 14 & & 5 & & & & & & & & 5 \\
\hline 13 & & 3 & & & & & & & & 3 \\
\hline 7 & 3 & & & & & & & & & 3 \\
\hline Total & 179 & 95 & 84 & 40 & 84 & 16 & 11 & 25 & 25 & 559 \\
\hline
\end{tabular}

mineral silicates. The ASi wet-alkaline extraction is prone to additional release of DSi from amorphous mineral silicates. Despite its flaws, ASi wet-alkaline extraction is for the moment still the most representative method to analyse for ASi (Saccone et al., 2007).

\subsection{Water and silica mass balances}

All calculations and statistical analyses were performed in $R(R$, 2006). Inlet and outlet culverts are the only exchange points with the river. Their dimensions are exactly known. Flow velocity was measured acoustically (Sontek "Argonaut"). Water mass balances were calculated with an averaged discharge value throughout the water column for every 2 min, assuring accurate volume-weighing of concentration values during all tidal phases. Measurements, calibration and operation of the flowmeters were performed by Flanders hydraulics research laboratory (W\&L) experts. Concentration profiles as well as nutrient discharges were calculated as

\section{Table 2}

Selection of samples analysed for ASi at different locations (see Fig. 1C) and during different campaigns

\begin{tabular}{lcccccccccr}
\hline $\begin{array}{l}\text { Location } \\
\text { May }\end{array}$ & $\begin{array}{c}\text { Jul } \\
\text { 06 }\end{array}$ & $\begin{array}{c}\text { Sep } \\
\text { 06a }\end{array}$ & $\begin{array}{c}\text { Sep } \\
\text { 06b }\end{array}$ & $\begin{array}{l}\text { Oct } \\
\text { 06 }\end{array}$ & $\begin{array}{l}\text { Mar } \\
\text { 07a }\end{array}$ & $\begin{array}{l}\text { Mar } \\
\text { 07b }\end{array}$ & $\begin{array}{l}\text { Jun } \\
\text { 07a }\end{array}$ & $\begin{array}{r}\text { Jun } \\
\text { 07b }\end{array}$ & Total \\
\hline 1 & 12 & 16 & 4 & 5 & 12 & 8 & 6 & 15 & 15 & 93 \\
2 & & 9 & 7 & 7 & 12 & & & 5 & 5 & 45 \\
6 & 6 & 5 & & & 12 & & & 5 & 5 & 33 \\
8 & & & 4 & 6 & 12 & & & & & 22 \\
3 & & 3 & & & 12 & & & & & 15 \\
17 & & 12 & & & & & & & & 12 \\
5 & 6 & & & & & & & & & 6 \\
4 & 6 & & & & & & & & & 6 \\
11 & 5 & & & & & & & & & 5 \\
Total & 35 & 45 & 15 & 18 & 60 & 8 & 6 & 25 & 25 & 237 \\
\hline
\end{tabular}


S. Jacobs et al. / Estuarine, Coastal and Shelf Science 80 (2008) 42-52

linear interpolations (Becker et al., 1988). ASi concentrations were measured on average 10 times (range 4-16) and DSi concentrations 19 times (8-53) along each tidal cycle at the culverts. Interpolation provided 700 values/tidal cycle, for discharge $(D)$ as well as concentrations. These values were used to calculate absolute mass balance by cumulative summing of $\left(D\left(\mathrm{~m}^{3}\right) \times[\mathrm{Si}]\left(\mathrm{mg} \mathrm{l}^{-1}\right)\right)$ along the instream and outstream phase separately. Stagnant phase and volumes entering through small leaks in the outstream culvert were not taken into consideration.

Total mass balances were first calculated as percentages $\left(\left(\sum\right.\right.$ (out) $-\sum($ in $\left.)\right) / \sum$ (in $\left.)\right)$ in order to compare between different tidal volumes, and then as absolute masses ( $\sum$ (out) $-\sum($ in $\left.)\right)$. In a conservative mass balance, it is assumed that there is no net import or export of water. However, due to inter-tide variations, stocking or surplus release of water volumes takes place. To compare between tides, this conservative correction was calculated as a percentage for each campaign, recalculated on the final mass balance and shown as a range. However, general patterns were not seriously influenced by this effect (Figs. 5 and 6 ).

Additional tidal features were measured in order to compare between tides: average flooding height was calculated from total volume of each entering tide and total surface of the study area, water temperature was continuously monitored at culverts, and DSi and ASi concentrations were monitored in adjacent river water. General relationships between silica delivery and these tidal features were explored through PCA and ANOVA analysis (Chevenet et al., 1994).

\section{Results}

\subsection{Concentration profiles}

DSi concentration profiles show different seasonal patterns (Fig. 4). Instream phases (see Fig. 3) are marked by steep

relative ASi delivery (\%)
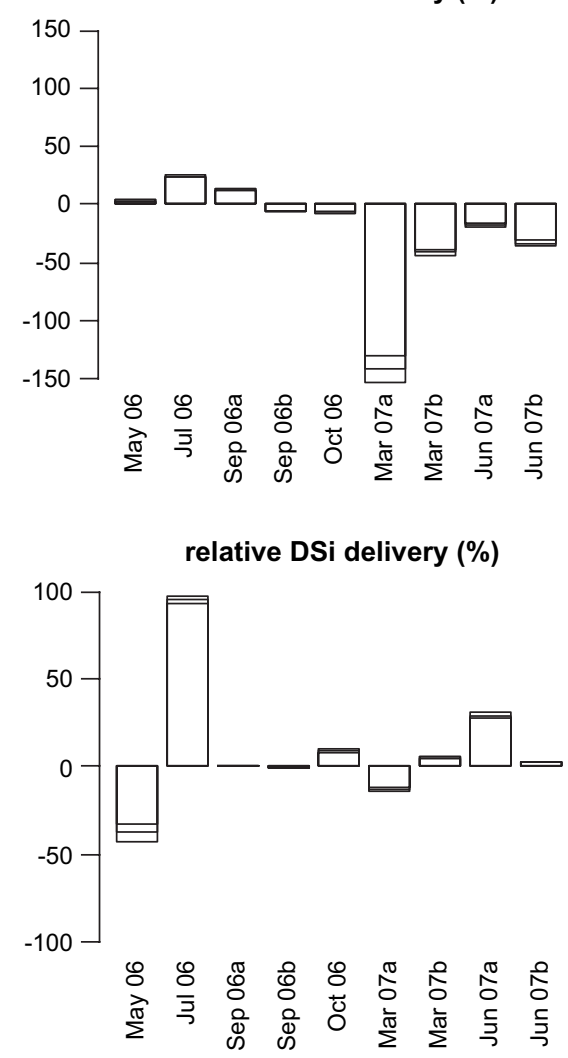

concentration changes, whilst the fluctuations during stagnant phase do not exceed $0.2 \mathrm{mg} \mathrm{l}^{-1}$. Outstream concentration profiles are highly variable and show increases, decreases or both: at starting concentrations below $2 \mathrm{mg} \mathrm{DSi}^{-1}$, concentrations increase with $125.0 \%$ and $126.6 \%$ (June 2007 in Fig. 4) or even with a factor 17 (July 2006 in Fig. 4) at final concentration. For instream concentrations higher than $2 \mathrm{mg} \mathrm{l}^{-1}$, profiles show slight increases $(10.5 \%$ to $31.9 \%$, May, September and October 2006 in Fig. 4). When instream concentrations become higher than $6 \mathrm{mgl}^{-1}$, profiles show a status quo or slight decrease (6\%, March 2007 in Fig. 4) towards final concentrations.

Concentration profiles of ASi present a more variable pattern over a smaller concentration range (not shown). Although for September 2006 and March 2007 only a limited number of samples was analysed for ASi, and differences are generally lower for ASi compared to DSi, there is a general evolution of increase or status quo (May, July, September 2006 and October 2006, not shown) towards strong ASi decrease in ASi- concentration profiles during later tidal cycle (March and June 2007b, not shown), with the exception of June 2007a.

\subsection{Mass balances}

Calculated DSi mass balances indicate enrichment of exported water in summer months (July 2006 and June 2007, Fig. 5, upper left), but also in late autumn (October 2006) and during one spring campaign (March 2007). Although July 2006 shows spectacular enrichment in percentage, absolute numbers (Fig. 5 upper right) are lower due to small water mass at neap tide, while the opposite is true for the 2007 campaigns. ASi mass balances confirm the transition from slight ASi delivery or status quo towards ASi caption by the marsh (Fig. 5, lower graphs).
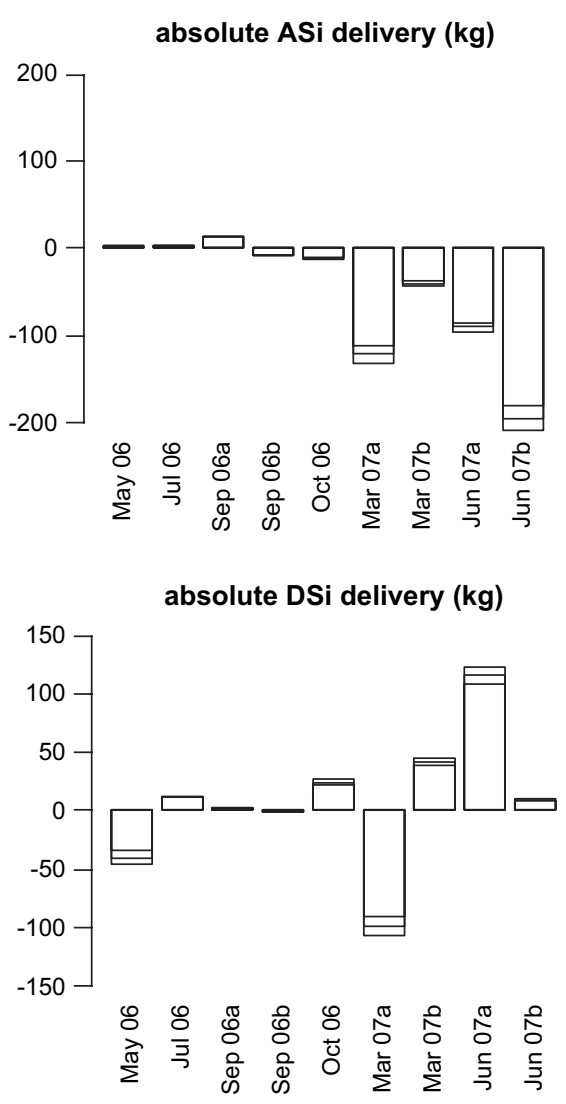

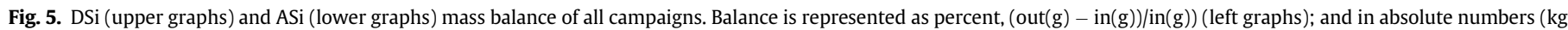
delivered/retained) (right graphs). Error bars represent deviation from conservative mass balance, represented as percent in both directions. 


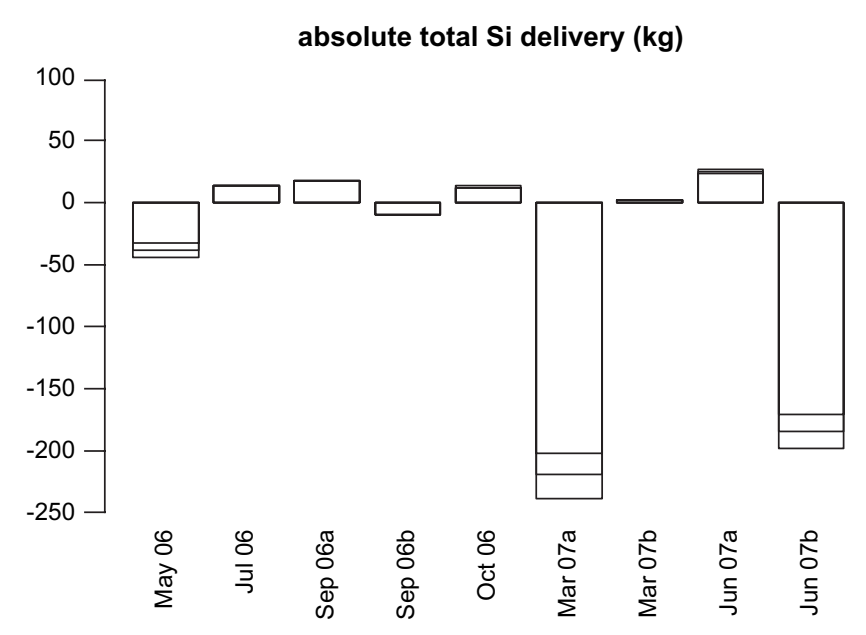

Fig. 6. Absolute total silica mass balance (DSi + ASi). Error bars represent deviation from conservative mass balance, represented as percent in both directions.

Total silica mass balance (Fig. 6) is strongly influenced by ASi retention, which adds up to Si retention in May and September 2006a and March 2007a (Figs. 5, 6) or overrules DSi delivery in June 2007b (Figs. 5, 6). Yet, despite large ASi retention in the March 2007b and June 2007a campaigns, DSi delivery can still be sufficient (Fig. 7, upper graphs) to provide the estuary with net silica (Fig. 6).

\subsection{Ephemeral and diurnal aspects}

Features of each tidal cycle are listed in Table 3. Non-numerical variable classes, being "day/night" show opposite differences in March vs. June 2007 campaigns. Variation of obtained numeric variables was maximized along two components (PCA correlation circle, see Section 2, Fig. 7). Parallel vectors indicate high correlation along the two components, whilst squared vectors are not correlated. Opposite direction indicates a negative correlation. Explicit $R$ squared and $p$-values depend on the amount of variation explained

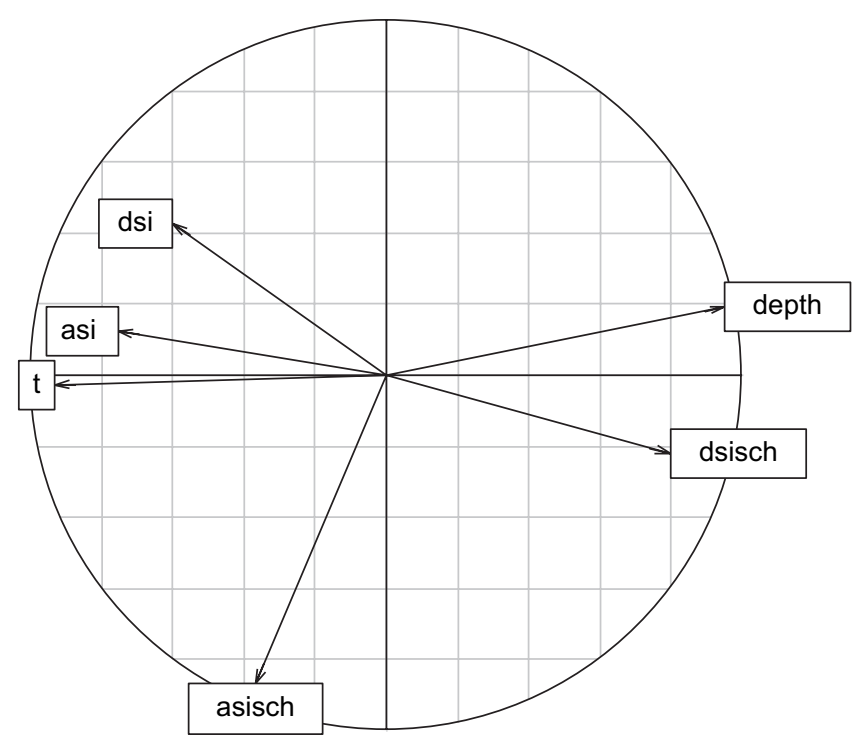

Fig. 7. PCA correlation circle of Table 3. Variation of numeric variables is maximized along two components. Mean water depth ("depth"), riverine ASi and DSi ("asisch" and " dsisch") and mean water temperature ("t") are shown with ASi and DSi percent delivery ("asi", "dsi"). Parallel vectors are highly correlated along the two components while squared vectors are not correlated. Opposite direction indicates a negative correlation. Explicit $R$-squared and $p$-values depend on the amount of variation explained by the components. by the components. This exploration of numerical variables shows potential effects of riverine DSi concentration ("dsisch" in Fig. 7), average flooding depth ("depth" in Fig. 7) and temperature ("t" in Fig. 7) on ASi- and DSi-balance ("asi" and "dsi" in Fig. 7), while the balances are completely independent of riverine ASi concentrations ("asisch" in Fig. 7).

Linear as well as logarithmic correlations were tested for numerical variables; highest significant $R$-squared values are shown. Percent DSi delivery was negatively correlated with the logarithm of riverine DSi concentration $\left(R^{2}=0.6397, p\right.$-value $0.0096)$, and the logarithm of mean water depth $\left(R^{2}=0.52, p\right.$-value 0.02 ), and not (significantly) correlated with temperature of outstream water, percent ASi delivery, or riverine ASi concentrations.

ASi delivery was negatively correlated with the mean water depth $\left(R^{2}=0.5317, p\right.$-value 0.0257$)$ and positively with the logarithm of temperature $\left(R^{2}=0.5787, p\right.$-value 0.0172$)$, ASi delivery was independent of riverine ASi concentrations (not shown).

\subsection{Spatial aspects}

Concentration profiles observed at other locations were not used for local mass balances, because water volumes and tidal phases were not measured separately for these locations. However, interesting patterns are visible when comparing local concentration profiles. During the first campaign (May 2006, Table 1), intensive sampling of 15 locations throughout the marsh took place. A clear gradient in increasing vs. decreasing DSi concentration profiles was observed (Fig. 8) despite the relatively small surface area, and the fact that the marsh was only functionally connected with the estuary less then 2 months before this campaign. Concentrations in the polder even out with the riverine concentration at bulk water entrance at the start of the instream phase. Concentrations appear unchanged during stagnant phase (minute 150 until 250 after instream in Fig. 8), but an hourglass pattern appears during outstream, when concentrations from different locations diverge strongly (Minute 300; Fig. 8). Typical retention habitat during the May 2006 campaign was the tidal pool (site 2 in Figs. 8 and 1C), whilst opposing behaviour is observed at the lower mudflat (site 3 in Figs. 8 and 1C). Locations situated in between these two average these two extremes, as do the outstream concentrations (site 1 in Figs. 8 and 1C). The hourglass structure returns, albeit less complete, in the other spatially sampled campaigns in the summer and autumn with net DSi delivery (not shown).

A similar spatial sampling took place for ASi (Table 2). Homogenization of concentration at instream and spatial patterns in general are less clear. Still, the lower mudflat site delivers ASi during the May, July, October 2006 and June 2007 campaigns. Tidal pool habitat delivers ASi during the July 2007 campaign. Other locations were year-round ASi-sinks.

\section{Discussion}

Numerous processes are involved in the silica exchange between tidal marsh and flooding water (Scheme 1). In the following overview, these processes are described and linked to the obtained data.

\subsection{Diffusive and advective transport}

In several systems, the importance of advective ground water fluxes to the estuarine nutrient balance has been emphasized (i.e. Herrera-Silveira, 1998; Hays and Ullman, 2007; Niencheski et al., 2007). However, this mainly concerned sandy coasts, where ground water fluxes are more important than in the dense clay soils characterizing the Schelde. 
Table 3

Percent DSi and ASi delivery and general tidal features of different campaigns

\begin{tabular}{|c|c|c|c|c|c|c|c|c|c|}
\hline \multirow[t]{2}{*}{ Season } & \multirow{2}{*}{$\frac{\mathrm{ASi}}{(\%)}$} & \multirow{2}{*}{$\frac{\mathrm{DSi}}{(\%)}$} & \multirow{2}{*}{$\frac{T_{\text {schelde }}}{\left({ }^{\circ} \mathrm{C}\right)}$} & \multirow[t]{2}{*}{ [DSi schelde $_{\text {e }}$ ] } & \multirow[t]{2}{*}{ [ASi schelde $]$} & \multirow{2}{*}{$\frac{\text { Mean water depth }}{(\mathrm{cm})}$} & \multirow[t]{2}{*}{ Time instream } & \multirow[t]{2}{*}{ Day/night } & \multirow{2}{*}{$\frac{\text { Tidal volume }}{\left(\mathrm{m}^{3}\right)}$} \\
\hline & & & & & & & & & \\
\hline May 06 & 3.6 & -37.1 & 19.5 & 4.2 & 1.5 & 30.0 & $6: 00$ & $\mathrm{D}$ & 24000 \\
\hline July 06 & 24.7 & 94.8 & 24.0 & 0.2 & 1.5 & 5.6 & 9:30 & $\mathrm{D}$ & 4500 \\
\hline Sep 06a & 13.2 & 1.0 & 18.0 & 4.0 & 1.5 & 42.5 & $18: 20$ & $\mathrm{~N}$ & 34000 \\
\hline Sep 06b & -6.3 & -0.2 & 22.5 & 4.2 & 2.0 & 43.8 & 6:35 & $\mathrm{D}$ & 35000 \\
\hline Oct 06 & -7.1 & 9.3 & 14.4 & 8.5 & 3.5 & 33.8 & 5:45 & $\mathrm{D}$ & 27000 \\
\hline Mar 07a & -140.7 & -12.2 & 7.9 & 6.2 & 1.5 & 96.3 & $16: 25$ & $\mathrm{~N}$ & 77000 \\
\hline Mar 07b & -40.6 & 5.6 & 9.0 & 6.3 & 1.4 & 96.3 & $5: 30$ & $\mathrm{D}$ & 77000 \\
\hline Jun 07a & -17.3 & 29.6 & 19.8 & 1.0 & 3.5 & 17.5 & $18: 46$ & $\mathrm{~N}$ & 14000 \\
\hline Jun 07b & -33.4 & 2.5 & 23.8 & 1.0 & 3.5 & 17.5 & 7:00 & $\mathrm{D}$ & 14000 \\
\hline
\end{tabular}

As previously explained, the key process in silica buffering by tidal marshes is the swift replenishing of dissolved silica (DSi) in the flooding water during seepage (e.g. Struyf et al., 2006). Sediment-water silica fluxes are normally assumed to be straightforward, with release due to dissolution of siliceous material, controlled by temperature (e.g. Hammond et al., 1985, Mortimer et al., 1998) and consequent diffusion in the water. However, calculated diffusive silica fluxes deviate from measured fluxes (Callender and Hammond, 1982; Mortimer et al., 1998), and the relatively low apparent rate constants obtained from pore water data cannot explain the observed fast dissolution kinetics (Nelson et al., 1995). Some diagenetic models invoke biogenic opal fractions (Wong and Grosch, 1978; Dixit and Van Capellen, 2002) and decreasing dissolution rate coefficient with advancing early diagenesis (McManus et al., 1995), or seek for solutions in Al content and specific surface area of biosiliceous fragments (Dixit et al., 2001). Other authors, however, have suggested the importance of bioturbation (Berner, 1980; Meile et al., 2005), resuspension (Mortimer et al., 1998), bioirrigation (Aller, 1965; Mortimer et al., 1998), advection and subsurface circulation patterns (Vanderborght et al., 1977) in diagenetic equations.

Empirical data on tidal marsh exchange revealed the importance of advective transport and gravitational drainage for silica delivery to the estuary (Struyf et al., 2006), suggesting a physical thrust of porewater refreshment by the flooding water, with tidal marshes acting as leaky dams (Hackney et al., 2000).

Our data confirm these conclusions: In all measured campaigns, DSi concentrations did not increase during stagnant phase or during bulk outstream, even when water depths were low throughout the site. DSi concentrations only increase when advective outflow or seepage starts. Seepage is characterized by the absence of continuous water bodies (overmarsh tide) in the marsh

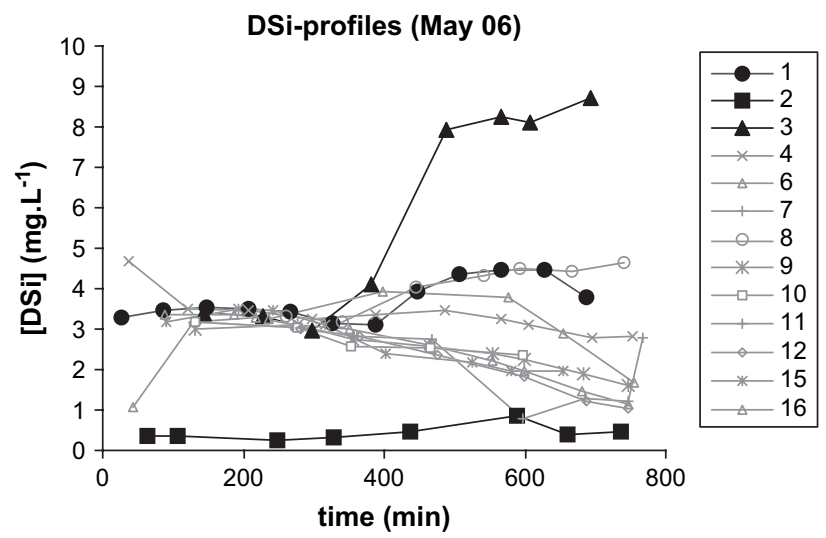

Fig. 8. DSi concentration profiles at all locations (see Fig. 3) sampled in the May 2006 campaign. Tidal pool (2) and lower mudflat (3), as well as outstream location (1) are shown in black, other locations in grey. (except in tidal pools). Outflow is then generated by small streams within the litter and surface layer of the marsh, or by advective horizontal outflow at creek banks from within the sediment. The bulk-seepage switch coincides with a decrease in flow velocity, visible in the outstream curve. In fact, the end of overmarsh tide and start of seepage coincides with a sudden increase in DSi concentrations in outstream water for almost all campaigns. This strengthens our hypothesis that DSi efflux from marshes to the estuary is a purely physical process of gravity-driven fluxes of Si-enriched pore and puddle water. This also explains why a recent modelling study, based only on diffusive fluxes directly into overmarsh tide, minimized the role of marshes in the estuarine silica cycle (Arndt et al., 2007). Empirical studies, including this one, have already indicated the importance of physical export processes (e.g. Vanderborght et al., 1977; Scudlark and Church, 1989).

The often observed decline in concentrations at the very end of the outstream phase is probably due to riverine water slowly entering the exit culvert. This leaking volume, which is important for fish migration, probably lowered concentrations at the culvert sample location during the last samples of each tide, when outstream had already stopped.

\subsection{Sedimentation and resuspension}

Sedimentation and recycling of suspended particulate silica are key processes in the marine and lacustrine silica cycle (Treguer et al., 1995; Bidle and Azam, 2001). However, in estuaries it has been shown that regeneration of silicic acid from particulate silica does not account for observed summer increases in silicic acid concentration (van Bennekom et al., 1974; Yamada and Delia, 1984). In some estuaries, at least during summer, regenerated silicic acid inputs exceed allochthonous outputs to the water column (Wilke and Dayal, 1982; Yamada and Delia, 1984). These inputs result from regeneration of silicic acid from recently deposited biogenic silica in diatomaceous debris in the sediments (Van Bennekom et al., 1974), and from biogenic silica in vegetation litter in tidal marshes (Struyf et al., 2007b).

In our study site, only a small proportion of the vegetation consisted of Phragmites australis during the experiments, although the proportion has recently increased. The remaining biomass consisted of species which do not accumulate silica, with the possible exception of Urtica dioica (Struyf et al., 2005). DSi delivery occurred equally from location 4 during the initial Urticadominated period, over the period of gradual decay of the Urtica vegetation, towards a rather bare mudflat stage. This may also indicate the dissolution of former buried phytoliths (plant silica bodies) from former vegetation (including crops like Zea mays). The observed, recent colonization by Phragmites australis and Typha angustifolia may enhance ASi available for dissolution and DSi delivery to the pore water (and to the estuary) in the long run, since poales such as the latter species are well known for their capacity to control silica fluxes (Blecker et al., 2006). 


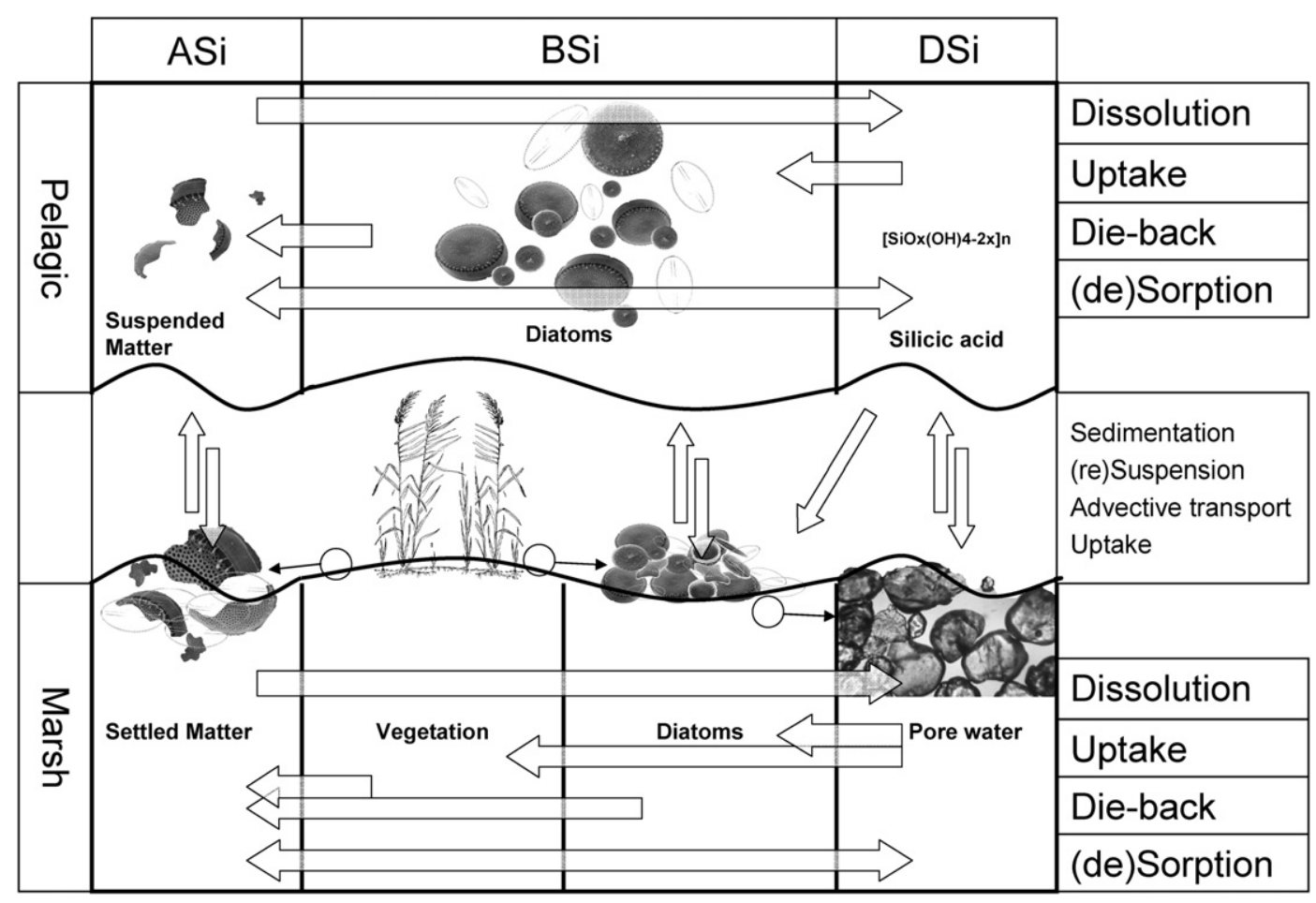

Scheme 1. schematic overview of processes involved in silica cycling in the intertidal ecosystem.

DSi delivery appears, up until now, to take place independent of vegetation composition. Therefore, we suspect dissolution of deposited diatomaceous debris, next to phytoliths from former vegetation (Urtica dioica, Zea mays), to be the source of this DSi. Sedimentation rates are several times higher in the CRT then at reference marshes, which is typical for the status of young marshes (Temmerman et al., 2004). Also, sedimentation rates are highest at observed DSi-source locations ( 3 in Fig. 1C), and lowest at typical DSisink locations (2 in Fig. 1C) (Vandenbruwaene, unpublished data).

When discussing patterns of ASi delivery, it is necessary to emphasize that ASi concentrations are probably underestimated, as only surface samples were taken, and suspended solids concentrations are expected to be higher near the bottom. Also, patterns for ASi are less clear than DSi, although for July 2006, October 2006 and June 2007 campaigns, sampling effort was increased. The ASi-concentrations drop between the moment of maximum instream discharge and the stagnant phase (not shown) probably points to important sedimentation, mostly during the stagnant phase. This is in accordance with our hypothesis that recently deposited materials contribute to the observed export of DSi, as settling sediments consist to a great extent of diatoms (De Schutter, J., unpublished data).

During outstream ASi-concentration patterns oppose DSi profiles. The pattern of ASi concentration increase during bulk outflow, and decrease in the seepage phase, shows that ASi is exported with the bulk water, while DSi is mostly exported during seepage. During the first months, marsh surface was mostly unvegetated, and no creeks were present (as shown in pictures, Fig. 2). Throughout the first summer small creeks developed, and vegetation and algal layers began to consolidate marsh soil while sedimentation and erosion zones became apparent, as in reference marshes. Probably, this has increased the deposition/resuspension ratio and promoted the high net ASi retention observed in the later campaigns.

\subsection{Diatom die-back and frustule dissolution}

Although the effects of environmental factors (such as salinity, $\mathrm{pH}$, temperature, etc.) on the solubility of silicic acid have been well studied (Greenberg and Price, 1975; Hurd and Theyer, 1975; Kamatani and Riley, 1979), silicic acid is likely to be found at concentrations considerably below saturation in the water column and surface sediments of most estuaries (Yamada and Delia, 1984). According to these last authors, factors affecting dissolution rate of biogenic silica and the amount of substrate available are of greater importance in determining the rate of regeneration of silicic acid in estuaries (Yamada and Delia, 1984). They point out that the deposition rate of biogenic material to the sediment surface, the salinity of the overlying water and the ambient temperature all have substantial effects on the silicic acid efflux from estuarine sediments. Bacteria have been shown to play a major role in dissolution of diatoms in oceanic (Bidle and Azam, 2001) and lake systems (Patrick and Holding, 1985). This bacterial mediation of potentially rapid and highly variable silica regeneration might also apply for intertidal marshes, especially in the lower tidal range, where decomposition of vegetation and consequent dissolution of phytoliths will play a less important role.

Our data confirm a positive temperature dependency (Yamada and Delia, 1984), since DSi delivery increases with temperature (Table 3 and Fig. 9), albeit not significantly. Maximum relative deliveries in our study were observed in summer, when surface and water temperatures of $35^{\circ} \mathrm{C}$ and more (Beauchard, O. pers. commun.) were observed on the mudflats and in small creeks during ebbs. Not only does increased temperature directly boost silica efflux from sediments (Yamada and Delia, 1984),it also enhances efficiency of bacterial removal of the organic carbon matrix from diatoms, increasing the surface area of naked silica exposed to dissolution and fastening chemical dissolution rates (Bidle and Azam, 2001). Moreover, the specific ebb conditions could affect bacterial activity on diatoms in a positive way, a mechanism that must be looked into.

Next to the temperature, ambient DSi concentrations certainly play a role, as relative export will increase with lower incoming DSi concentrations observed in summer. The exponential character of the relationships between DSi and concentration or volume of flooding water seems logical: if the marsh has a certain delivery 


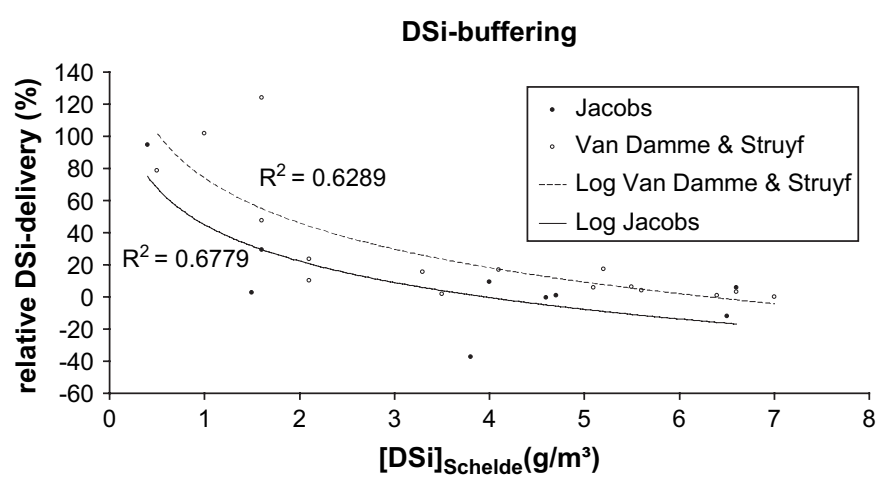

Fig. 9. Comparison of DSi-buffering capacity of reference tidal marshes (open points, dashed curve) and CRT (filled points, full curve). Reference data from Struyf et al. (2006) and Van Damme et al. (in preparation).

capacity, this standard amount will make up a bigger percentage of incoming DSi when incoming DSi concentration or volume is lower. Struyf et al. (2006) suggest this enhanced export at lower ambient DSi might be due to increased ASi dissolution at undersaturated conditions (e.g. Greenwood et al., 2001; Rickert et al., 2002; Passow et al., 2003). Also, the relationship could be magnified by temporal concurrence of low riverine DSi concentrations with periods of high temperature in summer. The June 2007 mass balance showed DSi delivery mainly taking place during the night. This suggests that day delivery might be lower, due to uptake of DSi by autochthonous diatoms. This diurnal aspect certainly deserves more attention.

\subsection{Si uptake by diatoms}

The DSi retention in the tidal marsh, until now not observed in important quantities (Struyf et al., 2006), may be the most striking difference of this study with earlier findings. The cause is almost certainly diatom uptake. In tidal pools, DSi concentrations dropped immediately after instream, while oxygen oversaturation indicated high diatom primary production (Maris, personal observation). However, in later campaigns benthic diatom populations were observed throughout the marsh (Jacobs, personal observation), as were decreasing DSi profiles during stagnant and bulk phase (not shown). Settling of the sediments and very low depth compared to the pelagic optimizes light conditions and surface aeration. During the stagnant phase, which is a specific feature of the CRT (Cox et al., 2006; Maris et al., 2007), optimal conditions for diatom production are thus provided throughout the marsh. The fact that the July 2006 campaign does not show this decrease in DSi is a consequence of the concentrations being close to zero at that time in the estuary, resulting in large relative DSi delivery during this campaign. Again, the day-night variation observed in Si delivery seems to confirm DSi uptake by diatoms (see earlier); silica incorporation by diatoms is halved in a dark situation (Azam and Chisholm, 1976), and surface temperatures at night are lower, resulting in higher DSi export during the night. The uptake process is dominant in spring, as low ambient DSi concentrations disadvantage production and promote relative export numbers in summer campaigns.

\subsection{Interactions}

In contrast to other systems where silica fluxes are studied, processes influencing silica cycling from tidal marshes are mostly separated in space and/or time (Scheme 2). It is possible that specific physical features of tidal marches account for their recycling capacities. Specific tidal patterns in CRT's influence the observed processes and their temporal distribution, most likely in favour of import processes (Scheme 2).

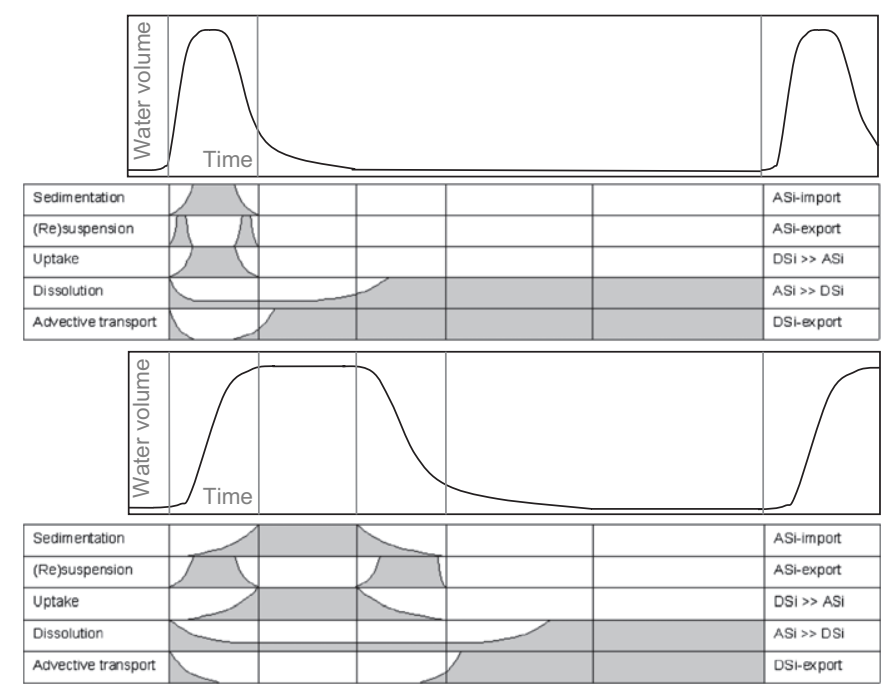

Scheme 2. Schematic overview of timeframes of some key processes in silica cycling in tidal marshes and in Controlled Reduced Tidal areas.

However, when DSi deliveries are compared with earlier measured reference tidal marshes, the difference is surprisingly small (Fig. 9). As the absence of Phragmites vegetation in the CRT has not provoked large differences in DSi delivery to the estuary up until now (Fig. 9; data from Struyf et al., 2006 and Van Damme et al., unpublished), we indicate the diatom population and dissolving frustules as the main biogenic silica stock for estuaries, although the presence of phytoliths of former vegetation might also play a role.

The above-mentioned difference (Fig. 9) is mainly governed by two DSi-retention events, which are caused by DSi uptake by diatoms, a process that occurs throughout the marsh at stagnant phase and in the tidal pool throughout the whole tidal cycle.

\subsection{Conclusions}

The typical tidal features of CRT areas influence their silica cycling, both through increased potential for uptake of DSi and enhanced sedimentation of ASi during the stagnant phase and in tidal pools. As such, they differ from reference tidal marshes (Scheme 2). However, when DSi deliveries are compared with earlier measured reference tidal marshes, the difference is surprisingly small. Export processes do not seem strongly limited by their decreased time budget. Moreover, at limiting conditions in the estuary, no DSi uptake in the stagnant phase took place, resulting in strong export of DSi. This indicates that CRT areas are capable of fast build-up of Si-recycling capacity and swift DSi delivery at limitation events. Despite the current absence of silica-accumulating wetland vegetation, CRT areas have the potential to fulfil their role as silica buffer in the estuary, both via diatom dissolution and dissolution of buried phytoliths. Additional research concerning the diatomaceous versus vegetation silica stock in intertidal mudflats and marshes is necessary, as well as estimates of process rates to determine the limiting factors of silica buffering by marshes. Our main conclusion is that recently constructed CRTs along estuaries are capable of a silica buffering role comparable to older, reference tidal marshes. Since this restoration technique can be implemented on lowered sites, which are less suitable for managed realignment, the CRT technique has to be represented in the ongoing debate on intertidal function and habitat restoration today.

\section{Acknowledgements}

The authors wish to thank the Flemish Government, Environment and Infrastructure department, W\&Z for the financing of the 
SIGMA and OMES project, which made this research possible. Thanks to Eva De Bruyn and Godelieve Clement for the ICP-analysis, and especially to Tom Van Der Spiet for lab work. We wish to express our gratitude to the Schelde research team; Stefan Van Damme, Tom Cox, Olivier Beauchard, Johnny Teuchies and Katrijn Van Renterghem for support during field and lab work and terrific research atmosphere. The remarks of two anonymous referees and Josie Meaney improved the manuscript substantially. We are most grateful to the freeware community for providing $R$ ( $R, 2006)$, JabRef, the Gimp, foobar2000, somaFM etc.

\section{References}

Aller, A.C., 1965. Quantifying solute distributions in the bioturbated zone of marine sediments by defining an average microenvironment. Geochimica et Cosmochimica Acta 44, 1955-1965.

Azam, F., Chisholm, S.W., 1976. Silicic-acid uptake and incorporation by natural marine-phytoplankton populations. Limnology and Oceanography 21, 427-435.

Becker, R.A., Chambers, J.M., Wilks, A.R., 1988. The New S Language. Wadsworth \& Brooks/Cole.

Berner, R.A., 1980. Early Diagenesis. Princeton University Press, Princeton and Oxford.

Bidle, K.D., Azam, F., 2001. Bacterial control of silicon regeneration from diatom detritus, Significance of bacterial ectohydrolases and species identity Limnology and Oceanography 46, 1606-1623.

Billen, G., Garnier, J., 1997. The Phison River plume, coastal eutrophication in response to changes in land use and water management in the watershed. Aquatic Microbial Ecology 13, 3-17.

Blecker, S.W., McCulley, R.L., Chadwick, O.A., Kelly, E.F., 2006. Biologic cycling of silica across a grassland bioclimosequence. Global Biogeochemical Cycles 20, GB3023.

Brzezinski, M.A., Nelson, D.M., 1996. Chronic substrate limitation of silicic acid uptake rates in the western Sargasso Sea. Deep-Sea Research Part II - Topical Studies in Oceanography 43, 437-453.

Brzezinski, M.A., Villareal, T.A., Lipschultz, F., 1998. Silica production and the contribution of diatoms to new and primary production in the central North Pacific. Marine Ecology-Progress Series 167, 89-104.

Callender, E., Hammond, D.E., 1982. Nutrient exchange across the sediment-water interface in the Potomac River Estuary. Estuarine, Coastal and Shelf Science 15, 395-413.

Chevenet, F., Dolédec, S., Chessel, D., 1994. A fuzzy coding approach for the analysis of long-term ecological data. Freshwater Biology 31, 295-309.

Chícharo, L., Chícharo, M.A., Ben-Hamadou, R., 2006. Use of a hydrotechnical infrastructure (Alqueva Dam) to regulate planktonic assemblages in the Guadiana estuary: basis for sustainable water and ecosystem services management. Estuarine Coastal and Shelf Science 70 (1-2), 3-18.

Childers, D.L., Day Jr., J.W., 1988. Direct quantification of nutrient and material fluwes between microtidal Gulf Coast wetlands and the estuarine column. Estuarine Coastal and Shelf Science 27, 486-494.

Childers, D.L., McKellar Jr., H.N., Dame, R., Sklar, F., Blood, E., 1993. A dynamic nutrient budget of subsystem interactions in a salt marsh estuary. Estuarine Coastal and Shelf Science 36, 105-131.

Conley, D.J., 2002. Terrestrial ecosystems and the global biogeochemical silica cycle. Global Biogeochemical Cycles 16.

Conley, D.J., Schelske, C.L., Stoermer, E.F., 1993. Modification of the biogeochemica cycle of silica with eutrophication. Marine Ecology-Progress Series 101, 179-192.

Costanza, R., Wainger, L., Folke, C., Maler, K.G., 1993. Modeling complex ecological economic-systems-toward an evolutionary, dynamic understanding of people and nature. Bioscience 43, 545-555.

Costanza, R., dArge, R., deGroot, R., Farber, S., Grasso, M., Hannon, B., Limburg, K. Naeem, S., Oneill, R.V., Paruelo, J., Raskin, R.G., Sutton, P., vandenBelt, M., 1997. The value of the world's ecosystem services and natural capital. Nature 387 253-260.

Cox, T., Maris, T., De Vleeschauwer, P., De Mulder, T., Soetaert, K., Meire, P., 2006. Flood control areas as an opportunity to restore estuarine habitat. Ecological Engineering 28, 55-63.

Cugier, P., Billen, G., Guillau, J.F., Garnier, J., Ménesguen, A., 2005. Modelling the eutrophication of the Seine Bight (France) under historical, present and future riverine nutrient loading. Journal of Hydrology 304, 381-396.

Dame, R.F. Chrzanowski, T. ., Bildstein, K. Kjeifve, B., McKellar, $H$., Nelson, D. Spurrier, J.D., Stancyk, S., Stevenson, H., Vernberg, F., Zingmark, R.G., 1986. The outwelling hypothesis and North Inlet, South Carolina. Marine Ecology-Progress Series 33, 217-229.

Davis, C.O., Breitner, N.F., Harrison, P.J., 1978. Continuous culture of marine diatoms under silicon limitation. 3. Model of Si-limited diatom growth. Limnology and Oceanography $23,41-52$.

DeMaster, D.J., 1991. Measuring biogenic silica in marine sediments and suspended matter. Geophysical Monograph 63, 363-367.

Derry, L.A., Kurtz, A.C., Ziegler, K., Chadwick, O.A., 2005. Biological control of terrestrial silica cycling and export fluxes to watersheds. Nature 433, 728-731.
Dixit, S., Van Capellen, P., 2002. Surface chemistry and reactivity of biogenic silica. Geochimica et Cosmochimica Acta 66, 2259-2269.

Greenberg, S.A., Price, E.W., 1975. The solubility of silica in solutions of elektrolytes. Journal of Physical Chemistry 61, 1539-1541.

Greenwood, J.E., Truesdale, V.W., Rendell, A.R., 2001. Biogenic silica dissolution in seawater - in vitro chemical kinetics. Progress in Oceanography 48,1-23.

Gribsholt, B., Boschker, H.T.S., Struyf, E., Andersson, M., Tramper, A., De Brabandere, L., Van Damme, S., Brion, N., Meire, P., Deheirs, F., Middelburg, J.J., Heip, C.H.R., 2005. Nitrogen processing in a tidal freshwater marsh, a whole ecosystem $15 \mathrm{~N}$ labeling study. Limnology and Oceanography 50, 1945-1959.

Hackney, C.T., Cahoon, L.B., Prestos, C., Norris, A., 2000. Silicon is the link between tidal marshes and estuarine fisheries, a new paradigm. In: Weinstein, M.P., Kreeger, D.A. (Eds.), Concepts and Controversies in Tidal Marsh Ecology. Kluwer Academic Publishers, London, pp. 543-552.

Hammond, D.E., Fuller, C., Harmon, D., Hartman, B., Korosec, M., Miller, L.G., Rea, R., Warren, S., Berelson, W., Hager, S.W., 1985. Benthic fluxes in San-Francisco Bay. Hydrobiologia 129, 69-90.

Hays, R.L., Ullman, W.J., 2007. Direct determination of total and fresh groundwater discharge and nutrient loads from a sandy beachface at low tide. Limnology and Oceanography 52 (1), 240-247.

Herrera-Silveira, J.A., 1998. Nutrient-phytoplankton production relationships in a groundwater-influenced tropical coastal lagoon Aquatic Ecosystem Health \& Management 1 (3), 373-385.

Humborg, C., Smedberg, E., Blomqvist, S., Mörth, C., Brink, J., Rahm, L., Danielsson, A., Sahlberg, J., 2004. Nutrient variations in boreal and subarctic Swedish Rivers, landscape control of land-sea fluxes. Limnology and Oceanography 49, 1871-1883.

Hurd, D.C., Theyer, F., 1975. Changes in the physical and chemical properties of biogenic silica from the Central Equatorial Pacific. I. Solubility, specific surface area, and solution rate constants of acid-cleaned samples. In: Gibb Jr., T.R.P. (Ed.), Analytical Methods in Oceanography. ACS, Washington DC, pp. 211-230.

Irigoien, X., Harris, R.P., Verheye, H.M., Joly, P., Runge, J., Starr, M., 2002. Copepod hatching success in marine ecosystems with high diatom concentrations. Nature 419, 387-389.

Kamatani, A., Riley, J.P., 1979. Rate of dissolution of diatom silica walls in seawater. Marine Biology 55, 29-35.

Kilham, P., 1971. A hypothesis concerning silica and the freshwater planktonic diatoms. Limnology and Oceanography 16, 10-18.

Kimmerer, W., 2005. Long-term changes in apparent uptake of silica in the San Francisco estuary. Limnology and Oceanography 50, 793-798.

Lancelot, C. Rousseau, V., Billen, G. Van Eeckhout, D., 1997. Coastal eutrophication of the Southern Bight of the North Sea, assessment and modelling. In: Sensitivity of North Sea, Baltic Sea and Black Sea to Anthropogenic and Climatic Changes. NATO-ASI Series 2, Environment, Vol. 27. Springer Verlag, Berlin, pp. 439-453.

Maris, T., Cox, T., Temmerman, S., De Vleeschauwer, P., De Mulder, T., Van den Bergh, E., Meire, P., 2007. Tuning the tide, creating ecological conditions for tidal marsh development in a flood control area. Hydrobiologia 588, 31-43.

McManus, J., Hammond, D.E., Berelson, W.M., Kilgore, T.E., Demaster, D.J., Ragueneau, O. Collier, R.W., 1995. Early diagenesis of biogenic opal, dissolution rates, kinetics, and paleoceanographic implications. Deep-Sea Research II 42, 871-903.

Meile, C., Berg, P., Van Capellen, P., Tuncay, K., 2005. Solute-specific pore water irrigation, implications for chemical cycling in early diagenesis. Journal of Marine Research 63, 601-621.

Meire, P., Ysebaert, T., Van Damme, S., Van den Bergh, E., Maris, T., Struyf, E., 2005. The Scheldt estuary, a description of a changing ecosystem. Hydrobiologia 540,1-11.

Mortimer, R.J.G., Krom, M.D., Watson, P.G., Frickers, P., Davey, J.T., Clifton, R.J., 1998. Sediment-water exchange of nutrients in the intertidal zone of the Humber estuary, UK. Marine Pollution Bulletin 37, 261-279.

Nelson, D.M., Brzezinski, M.A., 1990. Kinetics of silicic-acid uptake by natural diatom assemblages in 2 Gulf-Stream warm-core rings. Marine Ecology Progress Series $62,283-292$.

Nelson, D.M., Dortch, Q, 1996. Silicic acid depletion and silicon limitation in the plume of the Mississippi River, Evidence from kinetic studies in spring and summer. Marine Ecology-Progress Series 136, 163-178.

Nelson, D.M., Treguer, P., 1992. Role of silicon as a limiting nutrient to Antarctic diatoms-evidence from kinetic-studies in the Ross Sea ice-edge zone. Marine Ecology-Progress Series 80, 255-264.

Nelson, D.M., Tréguer, P., Quéguiner, B., 1995. Production and dissolution of biogenic silica in the ocean, Revised global estimates, comparison with regional data and relationship to biogenic sedimentation. Global Biogeochemical Cycles 9, 359-372.

Niencheski, L.F.H., Windom, H.L., Moore, W.S., Jahnke, R.A., 2007. Submarine groundwater discharge of nutrients to the ocean along a coastal lagoon barrier, Southern Brazil. Marine Chemistry 106, 546-561.

Officer, C.B., Ryther, J.H., 1980. The possible importance of silicon in the marine eutrophication. Marine Ecology-Progress Series 2 93-91.

Passow, U., Engel, A., Ploug, H., 2003. The role of aggregation for the dissolution of diatom frustules. FEMS Microbiology Ecology 46, 247-255.

Patrick, S., Holding, A.J., 1985. The effect of bacteria on the solubilization of silica in diatom frustules. Journal of Applied Bacteriology 59, 7-16.

$\mathrm{R}$, 2006. The R Foundation for Statistical Computing. http://www.r-project.org/ [2.4.1], 2006.

Rickert, D., Schlüter, M., Wallmann, K., 2002. Dissolution kinetics of biogenic silica from the water column to the sediments. Geochimica et Cosmochimica Acta 66, 439-455.

Saccone, L., Conley, D.J., Koning, E., Sauer, D., Sommer, M., Kaczorek, D., Blecker, S.W., Kelly, E.F., 2007. Assessing the extraction and quantification of 
amorphous silica in soils of forest and grassland ecosystems. European Journal of Soil Science 58, 1446-1459.

Schelske, C.L., Stoermer, E.F., 1971. Phosphorus, silica and predicted changes in algal quality in Lake Michigan. Science 173, 423-424.

Scudlark, J.R., Church, T.M., 1989. The sedimentary flow of nutrients at a Delaware salt marsh site, A geochemical perspective. Biogeochemistry 7, 55-75.

Smayda, T.J., 1997. Bloom dynamics, physiology, behavior, tropic effects. Limnology and Oceanography 42, 1132-1136.

Soetaert, K., Hoffmann, M., Meire, P., Starink, M., Van Oevelen, D., Van Regenmortel, S., Cox, T., 2004. Modelling growth and carbon allocation in two reed beds (Phragmites australis) in the Scheldt. Aquatic Botany 79, 211-234.

Spurrier, J.D., Kjerfve, B., 1988. Estimating the net flux of nutrients between a salt marsh and a tidal creek. Estuaries 11, 10-14.

Struyf, E., Van Damme, S., Gribsholt, B., Middelburg, J.J., Meire, P., 2005. Biogenic silica in tidal freshwater marsh sediments and vegetation (Schelde estuary, Belgium). Marine Ecology Progress Series 303, 51-60.

Struyf, E., Dausse, A., Van Damme, S., Bal, K., Gribsholt, B., Boschker, H.T.S. Middelburg, J.J., Meire, P., 2006. Tidal marshes and biogenic silica recycling at the land-sea interface. Limnology and Oceanography 51, 838-846.

Struyf, E., Temmerman, S., Meire, P., 2007a. Dynamics of biogenic Si in freshwater tidal marshes, $\mathrm{Si}$ regeneration and retention in marsh sediments (Scheldt estuary). Biogeochemistry 82, 41-53.

Struyf, E., Van Damme, S., Gribsholt, B., Bal, K., Beauchard, O., Middelburg, J.J., Meire, P., 2007b. Phragmites australis and Si-cycling in tidal wetlands. Aquatic botany $87,134-140$.

Struyf, E., Conley, D.J., in press. Silica: an essential nutrient in wetland biogeochemistry. Frontiers in Ecology and Environment.

Temmerman, S., Govers, G., Wartel, S., Meire, P., 2003. Spatial and temporal factors controlling short-term sedimentation in a salt and freshwater tidal marsh, Scheldt estuary, Belgium, SW Netherlands. Earth Surface Processes and Landforms $28,739-755$.

Temmerman, S., Govers, G., Wartel, S., Meire, P., 2004. Modelling estuarine variations in tidal marsh sedimentation, response to a changing sea level and suspended sediment concentrations. Marine Geology 212, 1-19.
Tessenow, U., 1966. Untersuchungen über den Kieselsäurehaushalt der Binnengewasser. Archiv fuer Hydrobiologie (Supplementband 32), 1-136.

Treguer, P., Nelson, D.M., Vanbennekom, A.J., Demaster, D.J., Leynaert, A., Queguiner, B., 1995. The silica balance in the world ocean-A reestimate. Science 268, 375-379.

Valiela, I., Teal, J.M., Deuser, W.G., 2007. The nature of growth forms in the salt marsh grass Spartina alterniflora. American Naturalist 112, 461-470.

Van Bennekom, A.J., Krijgsman-van Hartingsveld, E., Van der Veer, G.C.M., Van Voorst, H.F.J., 1974. The seasonal cycles of reactive silicate and suspended diatoms in the Dutch Wadden Sea. Netherlands Journal of Sea Research 8, 174-207.

Van Damme, S., Struyf, E., Maris, T., Ysebaert, T., Dehairs, F., Tackx, M., Heip, C. Meire, P., 2005. Spatial and temporal patterns of water quality along the estuarine salinity gradient of the Scheldt estuary (Belgium and The Netherlands), results of an integrated monitoring approach. Hydrobiologia 540 29-45.

Vanderborght, J.P., Wollast, R., Billen, G., 1977. Kinetic-models of diagenesis in disturbed sediments. 1. Mass-transfer properties and silica diagenesis. Limnology and Oceanography 22, 787-793.

Wang, W.C., Evans, R.L., 1969. Variation of silica and diatoms in a stream. Limnology and Oceanography 14, 941-944.

Whiting, G.J., McKellar, H.N., Spurrier, J.D., Wolaver, T.G., 1989. Nitrogen exchange between a portion of vegetated salt marsh and the adjoining creek. Limnology and Oceanography 34, 463-473.

Wilke, R.J., Dayal, R., 1982. The behaviour of iron, manganese and silicon in the Peconic River estuary, New York. Estuarine Coastal and Shelf Science 15 577-586.

Wolanski, E., Chicharo, L., Chicharo, M.A., Morais, P., 2006. An ecohydrology model of the Guadiana Estuary (South Portugal). Estuarine, Coastal and Shelf Science 70, 1-2. 85-97.

Wong, G.T.F., Grosch, C.E., 1978. A mathematical modal for the distribution of dissolved silicon in interstitial porewaters- and analytical approach. Journal of Marine Research 36, 735-750.

Yamada, S.S., Delia, C.F., 1984. Silicic-Acid Regeneration from Estuarine Sediment Cores. Marine Ecology-Progress Series 18, 113-118. 